International Journal of Linguistics, Literature and Translation

ISSN: 2617-0299 (Online); ISSN: 2708-0099 (Print)

DOI: 10.32996/ijltt

Journal Homepage: www.al-kindipublisher.com/index.php/ijllt

\title{
Emotional Analysis of G. M. Hopkins' Spring and Fall
}

\author{
Kahkasha Moin Quadri' $8(D) \triangle$, Dr. Haseeb Ahmed ${ }^{2}$ (D) and Dr. Mohammed Osman Abdul Wahab $\mathbf{8}$ (D) \\ ${ }^{1}$ Research Scholar, Department of English, Dr.Babasaheb Ambedkar Marathwada University, Aurangabad, 431004, India \\ 2Professor, Department of English, Maulana Azad College, Aurangabad, 431004, India \\ ${ }^{3}$ Assistant Professor, Department of English, Faculty of Languages and Translation, King Khalid University Abha, Saudi Arabia
}

$\triangle$ Corresponding Author: Kahkasha Moin Quadri, E-mail: kmquadri@gmail.com

ARTICLE INFORMATION ABSTRACT

Received: August 12, 2021

Accepted: September 18, 2021

Volume: 4

Issue: 9

DOI: $10.32996 /$ ijllt.2021.4.9.6

\section{KEYWORDS}

English poetry, Semantic analysis,

Syntactical analysis, Lexical analysis
This article critically focuses on the emotions created in the poetry of Gerard Manley Hopkins. It explores the various features responsible for creating feelings in poetry. Among them are word choice, sound choice and imagery. Moreover, it delves into the poem to anayse how devices such as alliteration, simile, metaphor, diction, and symbolism play a vital role. Appropriate implementation of these features create strong emotions in poetry. In most of his poems, Hopkins employed coinage words. In "Spring and Fall", he doubly used coinage words in a single - line. In the second line of the poem, he coined 'Goldengroove' and 'unleaving' and in the eighth line 'wanwood' and 'leafmeal'. The word 'Goldengroove' is not used for a place in reality yet, and it is a place that represents autumn's beauty. 'Golden groove also refers to the 'Garden of Paradise'. It indicates the four seasons of the year and the chronological phases of human life too. The words 'golden' and 'groove' are combined to form a single word. The word 'unleaving' encapsulates the noun 'leaf' employed as a verb possessing a negative prefix 'un', which means 'leaving leaves'. The coinage word 'unleaving 'is an Anglo-Saxon and comes in the category of pun. Another word, 'wanwood', is also a compound word. 'Wanwood' explains the pale condition of trees that have shed their leaves, so they seem to become 'wan' or pale. Initially, the word 'leafmeal' appears to be ambiguous, yet this ambiguity is expelled immediately.'Leafmeal' refers to the phrase 'leaf by leaf'. The two words 'wanwood' and 'leafmeal' are originated from Anglo- Saxon ring. Hopkins entitled the poem" Spring and Fall", which itself enhances strong emotion. The rhyme scheme's alteration in this innovative poem, "Spring and Fall", exhibits the speaker's feelings.

\section{Introduction}

"Spring and Fall" is one of the greatest poems of Hopkins. However, it is considered to be among his sad poems. Hopkins composed this poem during the spring season in 1880, when the poet was battling with intense personal distress. Hopkins wrote regarding this poem to Robert Bridges, as it is a little piece composed since I began this letter not founded on any real incident. I am not well satisfied with it. However, this poem endures and continues its great lyrical depth and emotions in which technical novelties are also in abundance. The poem conveys the message about the similarities between the low mortality of man and nature. The poem begins with an affectionate address by a father-confessor to an imaginary child. The word 'spring' from the title of the poem indicates two things the spring season, during which nature adopts an innovative look, and the 'Garden of Eden' where Adam and Eve lived happily before their infringement. The word 'fall 'from the title analogously indicates the autumn season during which leaves fall and, secondly, the 'Fall of Adam' (the punishment that he got for his infringements). The innocent Margaret who mourns in the wake of the golden leaves falling in autumn weeps, although she is not yet aware that it's about her mortality. The poem is based on human mortality. It is a kind of grief created by the poet owing to the fall of man.

\section{K C AL-KINDI CENTER \\ R D FOR RESEARCH AND DEVELOPMENT}

Your gateway to world-class research

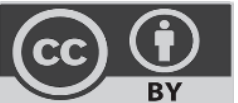

Published by Al-Kindi Center for Research and Development, London, United Kingdom. Copyright (c) the author(s). This open access article is distributed under a Creative Commons Attribution (CC-BY) 4.0 license 
Poetry exists when an emotion converts into thought and thoughts convert into words. According to the renowned poet Robert Frost, poetry is entirely based on emotion. In other words, poetry is the end product of emotion. The majority of the poems of Gerard Manley Hopkins are based on emotions. Although Hopkins composed the poem "Spring and Fall" in 1880, it was published in 1918. The title indicates that the poem is based on 'spring and fall", 'youth and age', 'life and death' etc. The poem addresses to a young child. Sporadically, it is believed that it was the poet's child, yet it was not so. As Hopkins being a Jesuit priest, could not have children. To impart emotions to the poetry, Hopkins makes use of different poetic devices discussed below:

Alliteration : Alliteration is a literary device in which some words, having similar first consonant sound, occur close together in a series" (Cuddon 1991). Example : 'A better butter makes a batter better.

'She sells seashells on the seashore.'

Alliteration does not depend upon letters but on sounds not-knotty /n/ alliterative, cigarette/s/ chase/s/ not alliterative. In our daily life, we notice the use of alliteration in companies' names to make it catchy and easy to remember-for example, Pay Pal, Coca-Cola, Life-Lock, etc.

The function of alliteration : (in literature, mainly poetry) It creates a musical effect in the text that enhances the pleasure of reading the literary piece. It makes reading and recitation of poem attractive, making the poem easy to recite and learn by heart. It gives flow and beauty to a piece of writing. It is used to emphasize something important that a writer or speaker would like to express. The phrases 'will weep', 'sorrow's springs', 'ghost guessed', and 'heart heard' indicates the use of alliteration in the poem.

Enjambment : "Is a type of literary device derived from the French word enjambment, which means stepping over or putting legs across. It can be defined as a thought or sense, phrase or clause in line of poetry that does not come to an end at the line break, but moves over to the next line"(Cuddon 1991). In simple words, enjambment runs on of a sense from one line, couplet, or stanza to the next without a significant pause. The opposite of enjambment is end-stopped when a line or poem ends with a period or with punctuation. Poets can achieve a fast pace or rhythm. Multiple ideas can be expressed usually without using semicolons, periods, and commas. It helps to make more vital the main idea that it might seem to be confusing with pauses. It allows a vision to continue beyond the limitations of a single line. It can surprise a reader by setting up one idea for the first time and then changing that idea in some way in the 2nd line. It forces the reader's eyes to the following line before they have entirely processed the thought creating tension between word and idea.

\section{Ah! ás the heart grows older \\ It will come to such sights colder \\ By and by, nor spare a sigh \\ Though worlds of wanwood leafmeal lie;}

The above poetic lines from the poem "Spring and Fall" show that Hopkins has also used enjambment.

Simile : "It is a comparison between items from different classes with the help of connectives such as 'like' or 'as' or 'then' or 'by' the use of a verb such as 'appears' or seems" (Cuddon 1991) For example : 'He fought like a lion on the battlefield.' Here a particular human being is compared with a lion. The lion is a symbol of bravery ; it means that the man is as brave as a lion.

Metaphor: "When a comparison is made between two, unlike things, without the connectives 'like' and 'as' it is called a Metaphorwhich is an implied comparison. Images suggest the meaning. A Metaphor suggests the comparison between two things not usually thought of as similar" (Cuddon 1991). The words 'spring' and 'fall' are directly compared with the stages of human life. Hence it is crystal clear that the poet has used metaphor in the title itself.

Rhyme : When two words have the same tone of the sound, that means they end with the same sound like 'bark' and 'park.' But the way rhyme is used in poetry is quite complex. Rhyme plays a vital role in poetry, and it is a structural element. There are two parts of the poem the 'content' (meaning of the poem inside) and the 'Form' (the way it's put together). Rhyme adds to the 'Form' or Structure of the poem. Both these elements are essential for reading and understanding the poem. The poem affects us not just because of what it's talking about yet also the way it's talking. Rhyme influences the way we feel as we are reading it. Rhyme can be silly, rhyme can be elegant, and rhyme can be uncomfortable; a good poet would choose the rhyme carefully because it influences the reader. Three kinds of rhymes are used, sound, position, and syllable. Let's see about sound. The traditional rhyme has the same terminal or ending sound. Yet it's not always the same, but if it has the same ending sound, we call it 'Full rhyme.'

Rhyme Scheme : "It is a pattern of rhymes within a unit verse. Each end of the rhyme sound is represented by a letter. If two lines have the same end rhyme sound, they will have same letter goes alphabetically. Rhyme scheme is applied in the case of end 
rhyme types" (Lennard 79). The rhyme scheme uses the letter of the alphabet to represent sounds to be able to usually 'see' the pattern. Rhyme and rhythm are the two attributes that create musical effect in poetry. In any music or English song, we find that lines don't rhyme, but still, they have a beat that creates a musical effect in it that comes from rhythm.

Imagery : To make the reader understand the poem more effectively, poets use imagery while writing a poem. Imagery is also an element of poetry. Imagery compares what one knows to something unknown. Therefore, one could describe an object and action known to the emotional state. Further, the Oxford Advance Learners Dictionary says, "imagery, means language that produces pictures in the minds of people reading or listening; eg: poetic imagery. Imagery is a process through which images or pictures of any objects are created in the mind of the reader" (Cuddon 1991). However, 'imagery' refers to the FIGURATIVE LANGUAGE in a piece of literature (Metaphor and similes). When we use simile or metaphor, we use image or imagery. Imagery also refers to all the words which appeal to the sense and feelings.

As there are five major sensory types, we have five types of imagery in the same manner. Imagery appeals to all the five senses with the help of words, phrases, and sentences. To create a picture in the reader's mind. When we describe something, it helps the reader smell it, see it, feel it, or touch it, taste it, or hear it. That is imagery ; it creates a good picture in the reader's mind. Here the words 'Goldengroove', 'leafmeal'and 'wanwood' appeal to the reader's senses.

Symbolism : In order to help the reader to understand the piece of poetry more easily, symbols are used. A symbol is an item that stands for something. Signs have literal as well as figurative meanings. 'Literal meaning' = actual meaning of the item 'Figurative Meaning' = representative meaning of the item. For example, the American flag's literal meaning is that it designates a country, and the Figurative sense designates that country's freedom. In the poem " Spring and Fall", the words 'spring' and 'fall' denote both literal and figurative meanings as seasons and are compared with stages of human life. The symbol is to represent one thing with the help of the other.

The symbol is a word used to represent something from what it looks at the surface level. It is to show something else and mean something else. It means to describe a particular word so that it co-relates many hidden words in it. In day-to-day life, there are many symbols, if it is raining. It is a blessing from God, and if a flood comes due to heavy rain, it is a curse from God. There are two types of symbols in English literature, namely conventional symbols and personal symbols. Conventional symbols are also called traditional symbols, which almost all poets use. At the same time, private symbols are also called unique symbols, which a particular poet uses.

\section{Literature Review}

Emotions occur in poetry because of choice of word, sound, imagery and consequently, all these combine to create a mood. A poet initiates with word choice or diction. "It is a noun and is defined as à style of speaking or writing as dependent upon the choice of words - the accent, inflection, intonation, and speech. Sound quality manifested by an individual speaker, usually judged in terms of prevailing standards of acceptability enunciation" (Lennard 2005).

Words encapsulate two kinds of meanings: denotation, the literal meaning of a word, and connotation, which combines cultural or emotional significance. The words 'childish' and 'childlike' possess similar denotations. Both the words refer to a person who acts like a child. Yet, their connotative meanings differ. 'Childlike' is a positive quality, while a 'childish' person is immature and usually annoying, indicating a negative connotation. Poets precisely contemplate the connotation of their words to enhance the emotional response of their readers. "Poetry is formalizing of thoughts and consolidating values, works firmly in the material of the common language of the time, limited by its conventions (Widdowson 1992).

The selection of the right sounds also plays a vital role in enhancing emotions. Depressing sounds and dreary rhythms create sad poems, whereas pleasant sounds create light and happy lyrics. The third and significant technique is imagery. Imagery is more effective than pictures. It appeals to other senses also. Any poetic line that appeals to the senses comprises either one type of imagery or another. Therefore, images and emotions go hand in hand. The poem begins with a question asked by the speaker to a young child Margaret. The speaker asks her whether she is grieving on her lost play - world. As winter is approaching Golden Groove is shedding its leaves. The speaker states that the child has its own belief, and it cares about the Heavens as much as it cares about man's objects. The speaker believes that as the child grows up, age will alter this innocent emotion, and the entire world of the forest will be leafless and disarray, and then Margaret would not be expressing sympathy.

Further, the speaker states that the child will weep then, too, for a different conscious reason. The speaker continues that the cause of sadness will bethe same. The speaker states that neither the child's mouth nor her mind yet articulates the reason as distinctly as she will be able to think as a grown-up, but Margaret is already mourning over her mortality. In this poem, the poet states about man's life. Primitively man inhabited in perfect purity and joy in the 'Garden of Eden', yet he has to undergo mortality and degeneration after lamentation. 
The use of the coinage word 'Goldengroove' in line second of the poem is highly evocative. For some, it is merely an unnecessary innovation, andthey believe it to be simply elucidation of trees, the leaves of which have changed their colors to red, yellow, or' golden'. The falling of the leaves of the 'Goldengroove' moreover acquires a broader outlookwhen correlated with the 'Garden of Eden'. The unleaving is similar to the things of man. Hence 'Goldengroove' might also denote the 'golden days of youth', the springtime of life.

Consequently, the seasons of the year and the chronological phases of man's life are unified in this single term. The terms 'world', 'ghost', and 'blight' provide the reader with a clue to read the poem regarding the 'Garden of Paradise', for which 'Goldengroove' is a happy coinage. Both the words 'spring and 'fall' exhibits double symbolism in the poem. As 'fall' denotes autumn and also man's fall from grace. Simultaneously, 'spring' denotes the cause of sorrow (the original sin) and spring of tears. In this poem, Hopkins has doubly coined two new words within a single line. In the inline second, he has coined 'Goldengroove' and 'unleaving' while in the eighth line '" wanwood' and 'leafmeal' are coinage words.The word 'unleaving' encapsulates the noun 'leaf' employed as a verb possessing a negative prefix 'un', which means 'leaving leaves'. The coinage word 'unleaving 'is an Anglo - Saxon and comes in the category of pun. Another word, 'wanwood', is also a compound word. 'Wanwood' explains the pale condition of trees that have shed their leaves, and therefore they seem to become 'wan' or pale. Initially, the word 'leafmeal' appears to be ambiguous, yet this ambiguity is expelled immediately.'Leafmeal' refers to the phrase 'leaf by leaf'. The two words 'wanwood and 'leafmeal' are originated from Anglo- Saxon ring.

The poem" Spring and Fall" is a lyrical poem quite perfectfor addressing a little child. Each line consists of four stressed syllables. The first eight lines of the poem encompass a sing-song effect. These lines of the poem are more complicated than the last seven lines of the poem.

Sprung rhythm is stressed syllables in close series, consequently forming the spring or bounce effect when spoken. It imitates natural speech. In this poem, the first two lines exhibit the use of sprung rhythm :

\author{
Márgarét, áre you gríeving \\ Over Goldengrove unleaving ?'
}

Due to 'sprung rhythm,' the poet can orchestrate the juxtapositions of stresses in uncommon ways. Occasionally in this poem kind of musical trait exists, particularly in places where we would expect a syllable to differentiate two stresses. There are two stressed words consecutively at some points in this poem, as in 'will weep' and 'ghost guessed'. The alliteration contributes to the emphatic slowing of the rhythm at these most earnest and dramatic points in the poem. Inscape is a specific attribute of a definite landscape or some natural objects that distinguish others. While stress is the experience of the reader regarding inscape, Hopkins employed inscape and instress in this poem by using terms such as Goldengroove, unleaving, leafmeal, etc.,

Rhyme: "Rhyme implies both consonants and vowels, onomatopoeic outcomes in poetry are attained by the alliterative and also assonated patterns" (Leech 1981). "The poem "Spring and Fall" is a short lyric poem consisting of one stanza and fifteen lines. Hopkins utilizes a rhyme scheme which forms seven pairs of couplets excluding line seven to nine that all rhyme" (Stephenson 1996). Notably, this series of lines reorganized the rhyme scheme. While the lines before and after following an AABBCC.... rhyme scheme, there is a trio of lines here that provide rhyming words, especially lines 7, 8 and 9, which end with the words "sigh", "lie", and "why".

"So far, this part has been observed as intermediate part in which the narrator is providing commentary which is more forwardlooking for this child, but this alteration of rhyme scheme thickens that difference" (Gardener 1967). This is the crucial change, similar to the peculiar change which the girl will undergo one time she comprehends "why" she has to "weep". The approximate rhyme of the scheme is AABBCCDDEEFFGG.The four stages of human life are very much similar to the four seasons. The spring season represents childhood or infancy, andthe summer season represents youth, the autumn season symbolizes middle age, and the winter season represents old age. Like all the seasons have their importance.

Similarly, the four stages of human life also have. As we have to prepare for the upcoming season, such as changing the clothes and type of food, we also have to prepare ourselves for the forthcoming stages in our lives. The thematic meaning of "Spring and Fall" is based on these facts of life.

\title{
3. Emotional Analysis
}

The title of the poem "Spring and Fall" requests us to relate the young girl, Margaret, in her insolence and directness of feeling, with the blossom time. Sometimes it is assumed that Margaret is a memory or fantasy. While sometimes, it is considered Margaret is a God-gifted child. It is also presumed that the speaker is older Margaret. Poetic devices such as imagery and personification in the poem describe the poet's sentiments in Margaret's form. The description of human life and mortality signifies the poet's youth in Margaret. 
Additionally, the poet explains and compares the phenomenon of natural beauty with his own life and mortality. Hence the theme of the entire poem signifies symbolism and imagery. Hopkins' selection of the American term "fall" preferably than the British "autumn" is intentional ; it relates the notion of autumnal decrease or decomposes along with the biblical fall of human from elegance. That ancient episode of loss began human mortality and pain, different from a young child's life, as Hopkins proposes (enormous poets have before him- especially the Romantics), resembles the Edenic condition of man before the fall. "Margaret's lives in a condition of euphony with nature that permits her to connect to her heavenly "Gold-engrave" with the similar commiseration she carries for mankind or, additional cynically, for the things of man" (Mariani 2008).

"Margaret experiences a sentimental crisis when squaring up to with the reality of death and decompose, which the falling leaves indicate. What engrossed the speaker regarding her anguish is that it indicates such a singular (and valuable) phrase in the maturing of a human being's compression regarding death and loss" (Mariana 2008). Just as Margaret has earlier reached a determined level of maturity, can she feel anguish at the beginning of autumn? The speaker is acquainted with what she does not, namely, that as she grows older, she will carry on to teach with similar grief, but with additional embarrassment regarding its actual meaning, and without the identical arbitrate commiseration for non-living things. ("Nor spare a sigh, / Though worlds of wan wood leaf meal lie"). The eighth line is preferably one of the most marvellous in all of Hopkins' work : The term "worlds" puts forward destruction and reduction that spreads without end, exceeded by the small "Golden grove" bounds appears so vast and notable to a child's insight. Loss is fundamental to man's experience, and it is complete and all-consuming. "Wan wood" conveys the proposal of paleness and sickness in the term "wan" and also issues a perfect elucidation of the fainting colours of the earth as winter slumbering. The "term" "leaf meal" that Hopkins coined in comparison with "piecemeal" conveys with sadness the feeling of wholesale scattered fallen leaves might strike an innocent and responsive mind.

In the concluding and heaviest segment of the poem, Hopkins recognizes what this grief is that Margaret perceives and will, he convinces us, continue to perceive, though in varied ways. The statement in the eleventh line that "sorrow's springs are the same" put forth not only that all griefs have a similar source but also that Margaret, who is related with springtime, constitutes a stage all individuals go through in coming to comprehend mortality and loss. What is so notable regarding this stage is that while the "mouth" could not utter what sorrow is for, nor the mind even expresses it quietly, a type of comp resending nonetheless materializes. It is a mumble to the heart, something guessed" at by the "ghost" or soul - an entirely intuitive idea of the reality that all sorrowing points back to the self : to one's pain of losses, and finally to one's impermanence. "Spring and Fall" poem consists of a lyrical rhythm relevant to address a child. It seems that Hopkins started composing musical support to the verse, although none of its copy remains extant. "The lines formulate couplets, and every line consists of four beats, similar to the featured ballad line, although they consist an unusual number of syllables. The sing-song effect this generates in the initial eight lines is complexed into something more uncomfortable in the last seven; the rhymed triplet at the core of the poem generates a center for this modification" (Stephenson 1981). Hopkins "sprung rhythm" meter helps him to arrange the proximity of stresses in uncommon ways. He occasionally inserts pauses, like musical rests, in places where we would hope a syllable to divide two stresses (for instance, after "Margaret" in line -1 and "Leaves in line-3). "Some other times, he lets the stresses stand in conjunctions for prominence, as in "will weap" and "ghost guessed" the alliteration here donates to the firm slowing of the rhythm at these serious and substantial points in the poem" (Gardener 1967).

\section{Conclusion}

The main objective of this research is to comprehend the spiritual prospective of G M Hopkins's poem "Spring and Fall". After the emotional analysis of the poem, this research puts forward the outcome of the analysis. This poetry exhibits intimate correlations between poetry and painting. His techniques of word painting and implementation of 'inscape' exhibits strong imagery of this poem. Through his innovative technique "sprung rhythm" Hopkins broke the form and pattern of the conventional poetic language. Literary devices are instruments used to create emotions in poetry. In this poem "Spring and Fall" Hopkins has also used some literary instruments to express his ideas regarding God's creations. The main significance of this research is to examine the multifarious poetic devices employed by Hopkins's in this poem. Use of simile, metaphor, alliteration, enjambment, symbolism creates a strong imagery in reader's mind. Surmising the above analysis, it can be inferred that Hopkins's "Spring and Fall" is full of emotions. In the poem's initial lines, Hopkins relates the innocence of Margaret by employing the word 'Spring' in the title of the poem itself. Hopkins used the American word 'Fall' instead of the word 'Autumn'. The term 'Golden Grove' in the poem exhibits the euphonic nature of Margaret. The eighth line, 'Nor spare a sigh, / though words of wan wood leaf meal lie', imparts strong evidence that Hopkins employed imagery, word choice, and sound choice to express his emotions through this poem. Therefore this research paper proves that Hopkins's "Spring and Fall" is packed with emotions. This research lacks the semantic perspective of the poem due to which it cannot be thoroughly studied. However, this research is a guideline for the researchers who wish to work on the same line. The readers of this paper can easily examine emotions of any poem. 
Acknowledgments: The authors extend their appreciation to the Deanship of Scientific Research at King Khalid University for funding this work under Research grant award number RGP. 1/ 370 / 42

Conflicts of Interest: The authors declare no conflict of interest.

\section{References}

[1] Cuddon J. A. (ed.), A Dictionary of Literary Terms and Literary Theory, Oxford, Cambridge: Blackwell Reference, 1991.

[2] Chambers, S. (2008). Hopkins's Poetics of Speech Sound: Sprung Rhythm, Lettering, Inscape (review). Victorian Studies 50(2):330-332. DOI: $10.1353 /$ vic. 0.0038

[3] Connor, G. (2004). Living with the Word: A collection of speeches, commentaries, letters \& poems. Chattanooga, Tenn.: George Connor Society

[4] Collins, T. J. \& Rundle, V. J. (2005). The Broadview Anthology of Victorian Poetry and Poetic Theory, concise edition. Broadview Press. p. 671672.

[5] Dembińska-Pawelec Joanna. (2013). Sprung rhythm in the poetry of StanisławBarańczak. PraceFilologiczne. Literaturoznawstwo, (3) 77-90.

[6] Delley, L. \&McAuley, J. D. (2012). The Fabb-Halle approach to metrical stress theory as a window on commonalities between music and language. Oxford University Press. DOI:10.1093/acprof:oso/9780199553426.003.0003

[7] Doyle, T. (1993). "What I do is me": Scotist Elements in the Poetry of Gerard Manley Hopkins ». The Hopkins Quarterly, 20(1/2), 3-21. doi: $10.2307 / 45241221$

[8] Drew, G.; Elizabeth; Connor (1966). Discovering Modern Poetry. Holt, Paperback. ASIN : B002CBSJ7Q

[9] Engle, P. \& Warren, C. (1968). Reading Modern Poetry. Scott, Foresman and Co., Glenview, IL; 2nd Revised edition. ISBN-13 : $978-$ 0673185242

[10] Fabb, N. \& Halle, M. (2008). Meter in Poetry: A New Theory. Cambridge University Press. ISBN- 0521713250

[11] Russell, Matthew. "SJ, "Father Gerard Hopkins, SJ, and His Poetry,"." The Irish Monthly 47 (1919): 441-8.. Retrieved from http://www.jstor.org/stable/20505358

[12] Geoffrey Hutchings (1991). Sprung Rhythm: The Ghost of a Prosodic Theory. English Studies in Africa, 34:2, 103-113. DOI: 10.1080/00138399108690883

[13] Goldsmith, R. (1976). The Selfless Self: Hopkins' Late Sonnets. The Hopkins Quarterly, 3(2), 67-75. doi:10.2307/45240753

[14] Gerber, H. (1951). A Syllabus for Creative Writing: Poetry. College English, 12(4), 227-229. doi:10.2307/372632

[15] General Subjects. (1975). Journal of Modern Literature, 4(5), 895-984. Retrieved from http://www.jstor.org/stable/3831011

[16] Green, D., Kirkpatrick, R., \& Wilson, E. (1968). Current Bibliography. Keats-Shelley Journal, 17, 1-54. Retrieved from http://www.jstor.org/stable/30212670

[17] Groves, P.L. (2011). "Opening" the Pentameter: Hopkins's Metrical Experimentation ». Victorian Poetry 49(2), 93-110. doi:10.1353/vp.2011.0015.

[18] Gardner, H.W., and N.H. MacKenzie, "Poems. 4th edition. Eds". London: Oxford, UP, Print. 1967.

[19] Habermas, T. \& Narrative, E. (2018). The Handbook of Linguistics, Second Edition. Wiley. 10.1017/9781139424615.

[20] Hill, G. (2005). Gerard Manley Hopkins' prosody: Sprung rhythm and 'Cynghanedd'. Poetry Wales 41(1):40-44

[21] Lennard, John. The Poetry Handbook A Guide to Reading Poetry For Pleasure and Practical Criticism 2.Ed New York: Oxford University Press, 2005.

[22] Leech, G.N., Semantics. Harmondsworth: Penguin, 1981.

[23] Mariani, Paul. Gerard Manley Hopkins: A Life. New York: Viking, Mariani, a poet, integrates Hopkins's spiritual and literary life to portray the life and works of Hopkins, 2008.

[24] Sevik, G. (2013). Music and Poetry: Hopkins, Sprung Rhythm, and the Problem of Isochrony.

[25] Stephenson, E. (1981). Hopkins' "Sprung Rhythm" and the Rhythm of "Beowulf". Victorian Poetry, 19(2), 97-116. Retrieved from http://www.jstor.org/stable/40035463

[26] Stewart, D. (2010). Semantic Prosody: A Critical Evaluation. Routledge.

[27] Stephenson, Edward A. "Hopkins' 'Sprung Rhythm' and the Rhythm of 'Beowulf."' Victorian Poetry 19.2 (1981): 97-116. JSTOR. Web. 23 October 2011. "Soundscape." OED. Oxford: Oxford UP, 1996. Print.

[28] Stevenson, Charles L. "The Rhythm of English Verse." The Journal of Aesthetics and Art Criticism. 28.3 (1970): 327-344. JSTOR. Web. (23 October 2011).

[29] Thornton, R. (2008). The Modern Language Review, 103(4), 1114-1115. doi:10.2307/20468054

[30] Ventre, R. J. (1978). Gerard Manley Hopkins: Sprung rhythm and meaning. Providence: publisher not identified. Retrieved from https://www.worldcat.org/title/gerard-manley-hopkins-sprung-rhythm-and-meaning/oclc/4735129

[31] Ward, B. (1990). Philosophy and Inscape: Hopkins and the Formalitas of Duns Scotus. Texas Studies in Literature and Language, 32(2), 214239. Retrieved from http://www.jstor.org/stable/40754929

[32] Whitehall, H. (1944). Sprung Rhythm. The Kenyon Review, 6(3), 333-354. Retrieved from http://www.jstor.org/stable/4332511

[33] Whitehall, H. (1944). Sprung Rhythm. Kenyon Review, 6: 333- 54.

[34] Wilson, C. R. (1999). The Idea of 'Musicality' in Hopkins' Verse. The Hopkins Quarterly, 26. 1-2, 27-55.

[35] Widdowson, H.G. Practical Stylistics: An Approach to poetry. New York: Oxford University Press, (5-64) (1992).

[36] Yadav, M., \& Yadav, M. (2018). An Analytical Study of Catholic Sufferings in the Poetry of Seamus Heaney. International Journal of Research, 5(7), 1350-1361. Retrieved from https://journals.pen2print.org/index.php/ijr/article/view/13289

[37] Yadav, M. S., Yadav, M. K., Quadri, K. M. (2021). Stylistics Art and Craft of Sprung Rhythm in G. M. Hopkins' The Windhover. Psychology and Education Journal, 58(2), 9741-9751. DOI: https://doi.org/10.17762/pae.v58i2.3829 